\title{
James Joyce's Home Rule Comet, Elvis Costello’s Anglo-Irish Agreement
}

\author{
By Dermot Kelly \\ College of the North Atlantic, Carbonear Campus
}

\begin{abstract}
Copyright (c) 2007 by Dermot Kelly. This text may be archived and redistributed both in electronic form and in hard copy, provided that the author and journal are properly cited and no fee is charged for access.
\end{abstract}

\begin{abstract}
It is a truism that Anglo-Irish relations did not progress in the eighty odd years between Joyce's Trieste lectures and articles and Elvis Costello's King of America album. If anything they regressed. As Declan Kiberd and others have noted, Joyce foresaw the partitioning of Ireland and, as Greil Marcus has shown, the dark melodies of Costello's 1986 album are an acrid response to Thatcherism. Tracks like "Sleep of the Just" and "Little Palaces" are threnodies of diaspora. Of course Joyce was prophetic and my reading of Ulysses enables me to fill in the backstory of Marcus's visceral lines about "Little Palaces" in his 1986 Artforum review: for instance, Bloom's speech from the dock when he is accused of assaulting the serving girl Mary Driscoll actually reveals the unhappiness of this immigrant's son. My paper traces continuities of Irish dispossession from Joyce's "Ireland, Island of Saints and Sages" lecture to Costello's "Little Palaces" on the one hand and from the Trieste lecture on Mangan to "Sleep of the Just" on the other. I conclude with reflections on Irish absurdism and the seachange in Joyce studies occasioned by the work of critics like Seamus Deane who foreshadowed the Northern Ireland peace process with essays like "Joyce and Nationalism" (1982).
\end{abstract}

Key Words. James Joyce, Elvis Costello, discrimination, Catholicism, punk, diaspora, emigrants, nationalism.

Resumen. Es un lugar común que las relaciones angloirlandesas no progresaron en los aproxidamente ochenta años que median entre las conferencias y artículos de Trieste de Joyce y el álbum Rey de América de Elvis Costello. Más bien experimentaron un retroceso. Como Declan Kiberd y otros han señalado, Joyce previó la división de Irlanda y, como Greil Marcus ha mostrado, las sombrías melodías del álbum de 1986 de Costello son una agria respuesta al thatcherismo. Temas como "El sueño de los justos" y "Pequeños Palacios" son lamentos sobre la diáspora. Sin duda Joyce fue profético y mi lectura del Ulysses me permite clarificar el trasfondo de las viscerales líneas de Marcus sobre "Pequeños Palacios" en su reseña de 1986 en Artforum: por ejemplo, el discurso de Bloom desde el banquillo de acusados cuando se le imputa haber asaltado a la criada María Driscoll en realidad revela la tristeza de este hijo de inmigrante. El artículo traza continuidades de desposesión irlandesa desde la conferencia de Joyce "Irlanda, Isla de Santos y Sabios" a "Pequeños Palacios" de Costello por una parte, y desde la conferencia de Trieste sobre Mangan a "El sueño de los justos" por la otra. Concluyo con reflexiones sobre el absurdismo irlandés y el cambio radical que para los estudios de Joyce ha supuesto el trabajo de críticos como Seamus Deane, quien prefiguró el proceso de paz de Irlanda del Norte en ensayos como “Joyce y el nacionalismo” (1982).

Palabras clave. James Joyce, Elvis Costello, discriminación, Catolicismo, punk, diáspora, emigrantes, nacionalismo. 
Racial oppression was a living memory for Joyce, as it is for Elvis Costello. You only have to read through the list of rights extended to the emancipated Catholic in the "Ireland, Island of Saints and Sages" lecture to hear how the trauma of discrimination runs through families and communities. Victims always think it can happen again and bullies count on this fear. "Can the back of a slave forget the rod?" Joyce asks in the Trieste lecture, a line Declan Kiberd quotes with relish. And then Joyce sounds the keynote of Catholic punk: "The truth is that the English government increased the moral value of Catholicism when they banished it." The next paragraph is worth quoting in full, keeping in mind that this is the twenty-five year-old who will soon complete "The Dead."

Now, thanks partly to the endless speeches and partly to Fenian violence, the reign of terror is over. The penal laws have been revoked. Today, a Catholic in Ireland can vote, can become a government employee, can practice a trade or profession, can teach in a public school, can sit in parliament, can own his own land for longer than thirty years, can keep in his stalls a horse worth more than 5 pounds sterling, and can attend a Catholic mass, without running the risk of being hanged, drawn, and quartered by the common hangman. But these laws have been revoked such a short time ago that a Nationalist member of parliament who is still living was actually sentenced by an English jury to be hanged, drawn, and quartered for the crime of high treason by the common hangman (who is a mercenary in England, chosen by the sheriff from among his mercenary colleagues for conspicuous merit in diligence or industry) (Mason and Ellmann 1989: 168).

These lines, written and delivered in 1907, resonate for me as I listen to "Little Palaces," a track from Elvis Costello's King of America, the 1986 album Greil Marcus rates as one of "the quietest punk records ever made" and one of "the truest" (1993: 7). Joyce's acrid tone is a harbinger of the wrenching alienation given voice in Costello's stripped down ballad. This is so because of a boomerang effect whereby the Catholicism of Irish emigrants and even their descendants became a mark of dispossession in twentieth century Britain. So while southern Ireland was being liberated, some children of the diaspora found themselves living out a remake of Irish history.
Declan Kiberd understands the global dimensions of colonial history and Greil Marcus has an intuitive grasp of Costello's Irishness. What I offer is a counterpoint of Kiberd and Marcus illuminating the Joycean state of mind I call Catholic punk. Consider these verses from "Little Palaces":

And the doors swing back and forward

From the past into the present

And the bedside crucifixion

Turns from wood to phosphorescent.

And they're moving problem families

From the South up to the North

Mother's crying over some soft soap opera

divorce.

And you say you didn't do it

But you know you did of course

And they'll soon be pulling down the little palaces.

It's like shouting in a matchbox

Made of plasterboard and hope,

Like a picture of Prince William

In the arms of John the Pope

There's a world of good intentions

And pity in their eyes,

The sedated homes of England

Are theirs to vandalize

So you knock the kids about a bit

Because they've got your name

And you knock the kids about a bit

Until they feel the same

And they feel like knocking down the little palaces.

(Costello 2005)

Greil Marcus hears "some great social dislocation" and "some great wrong" in the King of America album, acknowledging that the people in the tunes "speak like exiles" dogged by "shadowy homelessness" (1993: $311,313)$. Of course the great wrong is the historic subjugation of the Irish and the fact that it did not automatically cease after the dislocation endured by emigrants.

Even though Marcus is not a student of Irish political thought, he is too brilliant to miss the shadow of the Ulster conflict sputtering on under Thatcherism and the undeniable fact that it was a kind of defiance for a supposedly British pop musician to adopt an Irish idiom for a song like "Little Palaces" in 1986. As always, Joyce is prophetic and my reading of Ulysses allows me to fill in the backstory of Marcus's visceral response to the song in his Artforum review. Take Costello's 
Catholic references first: they are dialogic, as befits the changing times and places, but the ghost of Stephen Dedalus still haunts his bespectacled descendant across the Irish Sea. Softcore television martyrdoms compete with the phosphorescent crucifix for the mother's devotion. It is the lines about the "picture of Prince William in the arms of John the Pope" which cause Marcus puzzlement and which beg for a Joycean explanation. Surely Costello is offering a kaleidoscopic eighties update of Stephen's quip about being "the servant of two masters... one English and one Italian" (Joyce 1986: 17).

Marcus's zinging one-liners capture exactly how the feelings Costello dramatizes have their Joycean counterparts. Three lines from the review which lodge themselves in the mind are: "the struggle to communicate becomes its own subject matter...a form of speech is a form of morality...The tale of dislocation is itself dislocated" (1993: 312, 314). Think of the "long unintelligible speech" (Joyce 1986: 376) Bloom makes in Nighttown to defend himself against the charge of assaulting the serving girl Mary Driscoll. Remember the clichéd picture the stage direction's summary of the speech painted of "loveful households in Dublin city and urban district of scenes truly rural of happiness of the better land with Dockrell's wallpaper at one and ninepence a dozen, innocent British born bairns lisping prayers to the Sacred Infant" (Joyce 1986: 377). The opposite of a rebel's speech from the dock, this is the protestation of a loyal Irish subject, but what comes through the meaningfully inappropriate language of the stage direction is the unhappiness of an immigrant's son. Like Costello or even Joyce himself, Bloom probably does not completely understand what is eating at him. As Marcus says of "Little Palaces," "The singer cries out against some great wrong, but while he makes the song impossible not to understand emotionally, the exact nature of the great wrong evades him, forcing him into poetry, away from the plain speech the Irish ballad was made for" (1993: 313).

Critics such as Jim Miller were quick to note that in Costello's songs "personal relations are perceived as a metaphor for relations in society at large" (quoted in Marcus 229). So the domestic violence that punctuates the second half of "Little Palaces" is the discipline required of minorities in an assimilationist society. The "kids" whose experience Costello sings about with such choked rage are like the postwar Harlem teenagers James Baldwin writes of in his story "Sonny's Blues": "they were growing up with a rush and their heads bumped abruptly against the low ceiling of their actual possibilities" (1965: 104). The difference between the African-American and Irish idioms is that Baldwin, coming out of an evangelical tradition, testifies while Costello and Joyce are inheritors of Jesuitical indirection. Similarly, the "you" Costello addresses in the second half of the song is a spiritual descendant of Myles Joyce, the old Galway man wrongly hanged for the 1882 Maamtrasna murders, a unilingual Irish speaker unable to understand or make himself understood at his own trial, whom Joyce, in another 1907 piece, called "a symbol of the Irish nation at the bar of public opinion" (Mason and Ellmann 1989: 198).

"Sleep of the Just," the final track on King of America, is a punk aisling sung by a man stricken with remorse over his complicity in the betrayal of a woman. The song opens at an army checkpoint, but, rather than a state sanctioned love-across-the-barricades melodrama, Costello offers a tough-minded unease reminiscent of a Seamus Heaney poem or a Harold Pinter play, masterfully demonstrating the choreography of avoidance necessitated by an obdurate, claustrophobic conflict.

The soldier asked my name and did I come here very often

Well I thought that he was asking me to dance In my holy coat and hat and him in his red bonnet We'd have made a lovely couple but we never got the chance

And now you say that you've got to go Well if you must you must

I suppose that you need the sleep of the just. (Costello 2005)

Perhaps this is the kind of intimate, unsettling material Costello had hoped Shane MacGowan would write for the Pogues, more like the parables Heaney was composing at the time (which would appear in The Haw Lantern the following year) than the strident approach the London Irish band took to the Ulster situation in "Birmingham Six" after they had 
decided not to work with Costello as their producer. The "holy coat and hat" costume may well be indicative of Elvis's own look during this period: Dave Marsh spotted him “dressed like a rabbi” (2004: 559) at Bruce Springsteen's 1985 Slane Castle show. In the second verse, "Sleep of the Just" picks up steam, words and music placing the singer's unspoken love and the civil strife in aching counterpoint:

Well it was a powerful day and there were black crows in the road

And I kept my strong opinions to my chest

I suppose I should have told them that I was on fire for you

When the bus burst into flame, outside some place - 'The Poet's Rest'

(Costello 2005)

In fact Costello was moving to Ireland and would soon give a song to Christy Moore. As he takes "Sleep of the Just" to the bridge, the song's narrative reaches its climax with the desecration of the girl who finds herself "pinned up upon the barracks wall in her hometown," presumably someone from a republican enclave whose brother is in the British Army ("she never mentions him"), the whole sad conflicted situation recalling nothing so much as Joyce's sentences about the Dark Rosaleen figure at the end of his Trieste lecture on Mangan.

The figure that he adores has the appearance of an abject queen to whom, because of the bloody crimes she has committed and the no less bloody crimes committed against her by the hands of others, madness has come and death is about to come, but who does not wish to believe that she is about to die, and remembers only the rumour of voices that besiege her sacred garden and her lovely flowers that have become pabulum aproram, food for wild boars. Love of grief, despair, high-sounding threats - these are the great traditions of the race of James Clarence Mangan, and in that impoverished figure, thin and weakened, an hysterical nationalism receives its final justification (Mason and Ellman 1989: 185-186).

There is criticism that captures the grim allure of Irish republicanism among those who find in it a remote vindication of some obscure family shame. Think of Padraig O’Malley's characterization of the nationalist New Ireland Forum report from 1984 as reflecting "the passive-aggressiveness that is often the hallmark of the emancipated victim who continues to take refuge in a culture of learned helplessness" (1990: 218). And in the story of Irish culture's long ascent from marginal status to twenty-first century eminence, Elvis Costello's turn to the ballad form in the eighties has its part, the singer's lyrics distilled from a thousand barroom discourses and kitchen conversations. It is thanks in no small part to the cultural context represented by writers like Joyce, Yeats and Beckett that an artist with Costello's talent would revisit this tradition after studiously ignoring it at the start of his career. Of course, when it came to wrestling with the ingrained sense of Catholic Irish inferiority, Joyce got there first: we all remember Stephen Dedalus approaching Trinity College in Chapter V of A Portrait, assailed by the fear "that he would never be but a shy guest at the feast of the world's culture" (1999: 154).

As the vignette of photographic exploitation comes to its militaristic denouement in "Sleep of the Just" what emerges is an ultrasound image of power relations. As with Pinter's 1988 drama of political detention, Mountain Language, Belfast is not named as the locus of coercion, but any British audience would note the telltale signs. Here are the song's final verses:

A girl woke up in a naked light and said, 'Oh no not again'

He even looked like her brother in the army but she never mentions him

He'll be tucked up in his bed tonight with his dirty pictures girl

Sayin 'You're some mother's daughter you know or is it immaterial girl'

Now she's pinned up upon the barracks wall in her hometown

All the soldiers taking turns with her attention

And as they speculate what she'd be like beneath that thin nightgown

His family pride was rising up as he cast his eyes down

(Costello 2005)

Greil Marcus ends his Artforum review with the album's last line. 
'I suppose you need the sleep of the just,' Costello sings as King of America closes sings it slowly, beautifully, as if the thought had cost him something - but while it is clear that everyone on the album needs that rest, it's also clear that no one deserves it (1993: 314).

In the eighties militant Irish nationalism was receiving its justification from another "impoverished figure, thin and weakened," that of hunger striker Bobby Sands; the IRA nearly succeeded in an attempt to kill Margaret Thatcher and in 1986 Patrick Magee was convicted for his part in the Brighton bombing, an attack conceived as revenge for Thatcher's intransigence in the face of the prison protests. The title poem of Seamus Heaney's 1987 volume The Haw Lantern refers to the search of Diogenes for “one just man," ending up in a mood remarkably similar to that of Costello's "Sleep of the Just":

The wintry haw is burning out of season, crab of the thorn, a small light for small people,

wanting no more from them but that they keep the wick of self-respect from dying out, not having to blind them with illumination.

But sometimes when your breath plumes in the frost

it takes the roaming shape of Diogenes with his lantern, seeking one just man; so you end up scrutinized from behind the haw

he holds up at eye-level on its twig,

and you flinch before its bonded pith and stone,

its blood-prick that you wish would test and clear you,

its pecked-at ripeness that scans you, then moves on (1987: 7).

By 1988 Harold Pinter's searing prison drama Mountain Language was performed at the National Theatre and, although it may or may not have been inspired by the treatment of Kurdish fighters in Turkish jails, it certainly had a particularly Irish resonance, as Anthony Roche has pointed out (Michael Billington's biography includes Pinter's acknowledgement of the connection). The eighties saw a seachange in Joyce studies, as critics like Seamus Deane cast the novels in terms suggested by the late twentieth century AngloIrish dynamic. The decade had begun, it must be remembered, with Hugh Kenner tartly dismissing the Fenian Kevin Egan as "a maker of political statements in the Irish mode" (1980: 39). Consider the difference of perspective in Deane's "Joyce and Nationalism" essay, published in the centenary of Joyce's birth, just two years after Kenner's Ulysses, where the Irish critic set the tone for much of what was to come in the Field Day pamphlets by observing of Joyce: "He had learned from Irish nationalism the power of a vocabulary in bringing to existence that which otherwise had none except in the theatre of words" (1982: 181).

It took almost a decade and a half for the main political players in the Northern Ireland conflict to catch up to the critics, although Gerry Adams of Sinn Fein was reading the Field Day pamphlets, particularly Seamus Deane's, as his 1986 book The Politics of Irish Freedom demonstrates. Adams was not the only one who seemed to be monitoring the cultural tradewinds. In the mid-eighties it became customary for British and Irish statesmen to refer to the Catholic minority in the North as "alienated" (Coogan 1995: 510), a word right out of the standard text for beginners in Beckett studies, Martin Esslin's The Theatre of the Absurd (1969: 361). So a faint shade of green was seeping into the Anglo-Irish dynamic at the precise moment when, in the words of Peter Murphy, Elvis Costello was marrying "the lyricism and melancholia of Irish music with an Anglocentric sensibility” (Lalor 2003: 886).

In the final analysis it has to be admitted that the Irishness of artists as diverse as John Lydon, Elvis Costello, Boy George and Morrissey endowed them with a healthy sense of absurdism. This absurdist sensibility is articulated by Anthony Cronin in the chapter he contributed to the novel Yeats is Dead! Hilariously, Cronin praises Fianna Fail, the party of de Valera, as twenty-first century inheritors of an absurdist tradition. Listen to the Garda Commissioner briefing a subordinate as they go to report to the Minister of Justice on the tangled case concocted by fifteen Irish writers and edited by Joseph O'Connor.

If it was one of the old gang now, Burke or somebody who understood human failings and complications, then you could tell the whole story. But this gang are not like that, the Fine Gaelers in particular. They have a limited grasp of the human aspect of things. They're 
limited both mentally and morally.

They don't understand the grey areas, what you might call the ambiguities. They don't really understand human nature. They want everything cut and dried. There's no use saying to any of this gang that it looks very complicated and it's all a bit of a mystery because of the general oddness and confusion of human affairs. They're not prepared to admit that aspect of things, what you might call the grotesque aspect, the unprecedented, the bizarre, you know what I mean, no two situations ever being the same from the dawn of time. They want everything cut and dried, the reason for this, the reason for that, who's to blame and who's not to blame (2001: 102).

This is funny stuff from the author of one of the best chapters on Joyce, "The Advent of Bloom” in A Question of Modernity (1966). But the really exquisite comedy of "the grotesque aspect, the unprecedented, the bizarre, you know what I mean, no two situations ever being the same from the dawn of time" plays on an acronym, GUBU, for "grotesque, unbelievable, bizarre and unprecedented," devised by Conor Cruise O’Brien from Taoiseach Charles Haughey's words and, as The Encyclopedia of Ireland tells us, "widely used to describe some of the strange incidents that continue to dog Irish governments" (Lalor 2003: 462). Anthony Cronin worked as cultural adviser to Haughey and it may well have been his Joycean influence that led to the Taoiseach quoting the line about "the new Bloomusalem in the Nova Hibernia of the future" (Joyce 1986: 395) while announcing plans for the International Financial Services Centre in the Dublin docklands in June 1987.

What we are talking about here is the idea that Elvis Costello experiences the Anglo-Irish dynamic as a matter of painful complexity in his own sense of himself, an experience shared by Anthony Cronin and Seamus Heaney. And even Pinter, son of a Jewish family in Hackney, has made the intuitive leap of discovering his own Irish side after spending a crucial period of apprenticeship in Ireland. It is a truism that Anglo-Irish relations did not progress in the eighty odd years between Joyce's Trieste lectures and articles and Costello's King of America. If anything they regressed. In the "Ireland, Island of Saints and Sages” lecture, Joyce foretells the partitioning of Ireland, personifying England as a cunning empress:

Her principal preoccupation was to keep the country divided, and if a Liberal English government that enjoyed the full confidence of the English voters were to grant a measure of autonomy to Ireland tomorrow, the conservative press of England would immediately begin to incite the province of Ulster against the authority in Dublin (Mason and Ellmann 1989: 166).

Flash forward a few generations to Thatcher's hamfisted response to Irish nationalism and you see Joyce's nightmare coming true. The writer John Kelly was a student at Queen's University Belfast when Thatcher dismissed the nationalistic findings of the New Ireland Forum in her typically highhanded way. He reproduces the mood on campus in Sophisticated Boom Boom, a novel that explains just about everything in terms of popular music.

The vicious and cruel mouth of Thatcher was everywhere. The Überbitch with an umlaut. Students had protested, marched and shouted Maggie, Maggie, Maggie! Out, Out, Out! through bullhorns and indifference, but pretty soon we were a defeated and cowed shower spiritless and dulled.

That it was Northern Ireland made things far more complicated and disappointing. Students' Union meetings were grim shouting matches where the Young Unionist, Tory, Reaganite, Pro-Nuclear, Tweed Jacket, Support the Contras, Friends of Israel, nosense-of-humour Christian faction would shout words like scum at the Marxist, Republican, Homosexual, Sandinistan, Shinner, Anarchist, feckless Alcoholic brigade across the room.

And then they would shout back. It was ugly, depressing and tiresome stuff (2004: 171).

It is not hard to see which side would be listening to King of America, the Clash's Sandinista!, the Smiths' Meat is Murder, maybe even Culture Club's Kissing to $\mathrm{Be}$ Clever. Irvine Welsh has shown himself to be remarkably sensitized to these nuances: the mostly Catholic denizens of Trainspotting (1993) follow Irish-inflected artists like Costello, the Smiths and the Pogues while Detective Inspector Bruce Robertson, the bigoted voice of the later Welsh novel Filth (1998), soothes his jingoistic breast with 
such established rock acts as Deep Purple, Ozzy Osbourne, Iron Maiden and Foreigner.

This is not to say that things would never get better and that, with hindsight, the portents cannot be seen. Even as Costello was coming up with the dark melodies of "Little Palaces" and "Sleep of the Just" a process was beginning, first with the immediate aim of serving the interests of the administrations in Dublin and London, that is, cutting off electoral support for Sinn Fein. The AngloIrish Agreement of 1985, which gave the Dublin government a consultative role in the affairs of Northern Ireland, can now be seen as the crucial first step in the long journey towards parity of esteem for both sides in the North. What came to be known as the peace process would have been perfectly well understood by Joyce, if the articles and lectures he produced in Trieste are anything to go by. His indictment of the Irish parliamentary party at the end of the "Home Rule Comes of Age" article, for instance, springs from the mind of one who knew all about what could be called the root causes of physical force nationalism. I believe Elvis Costello's "Little Palaces" and "Sleep of the Just" are products of a similar mind and, not only that, they offer listeners insight into the emotional and spiritual knot the peace process would begin to undo not just in Ireland but in such gateway cities as Birmingham, Manchester, Liverpool and London too.

\section{Works Cited}

Adams, Gerry. 1986. The Politics of Irish Freedom. Dingle: Brandon Books.

Baldwin, James. 1965. Going to Meet the Man. New York: The Dial Press.

Billington, Michael. 1996. The Life and Work of Harold Pinter. London: Faber and Faber.

Coogan, Tim Pat. 1995. The I.R.A. London: HarperCollins.

The Costello Show [Featuring Elvis Costello]. King of America. Rhino, 2005. Originally issued on Columbia, 1986.

Cronin, Anthony. 1966. A Question of Modernity. London: Secker and Warburg.

Deane, Seamus. 1982. “Joyce and Nationalism.” James Joyce: New Perspectives. Ed. Colin MacCabe. Bloomington, Indiana UP.

Esslin, Martin. 1969. The Theatre of the Absurd. New York: Anchor Books.

"Finance Dublin - Milestones of the IFSC.” 20 December 2005.

$<$ http://financedublin.com/supplements/display $>$.

Heaney, Seamus. 1987. The Haw Lantern. London: Faber and Faber.

Joyce, James. 1999 (1916). A Portrait of the Artist as a Young Man. London: Penguin. 1986 (1922). Ulysses. New York: Vintage Books.

Kelly, John. 2004. Sophisticated Boom Boom. London: Vintage.

Kenner, Hugh. 1980. Ulysses. London: George Allen \& Unwin.

Kiberd, Declan. 1995. Inventing Ireland. London: Jonathan Cape.

Lalor, Brian, ed. 2003. The Encyclopedia of Ireland. New Haven: Yale UP.

Leeming, David. 1994. James Baldwin. New York: Alfred A. Knopf.

Marcus, Greil. 1993. In the Fascist Bathroom: Punk in Pop Music 1977-92. Cambridge, Mass.: Harvard UP.

Marsh, Dave. 2004. Bruce Springsteen, Two Hearts, The Definitive Biography, 1972-2003. New York: Routledge.

Mason, Ellsworth and Richard Ellmann, eds. 1989. The Critical Writings of James Joyce. Ithaca: Cornell UP.

O’Connor, Joseph, ed. 2001.Yeats is Dead! A Mystery by Fifteen Irish Writers. New York: Alfred A. Knopf.

O'Malley, Padraig. 1990. Biting at the Grave: The Irish Hunger Strikes and the Politics of Despair. Belfast: The Blackstaff Press.

Pinter, Harold. 1988. Mountain Language. London: Faber and Faber.

Roche, Anthony. 2001. "Pinter and Ireland.” The Cambridge Companion to Harold Pinter. Ed. Peter Raby. Cambridge: Cambridge UP.

Welsh, Irvine. 1993. Trainspotting. London: Secker and Warburg. . 1998. Filth. London: Jonathan Cape. 